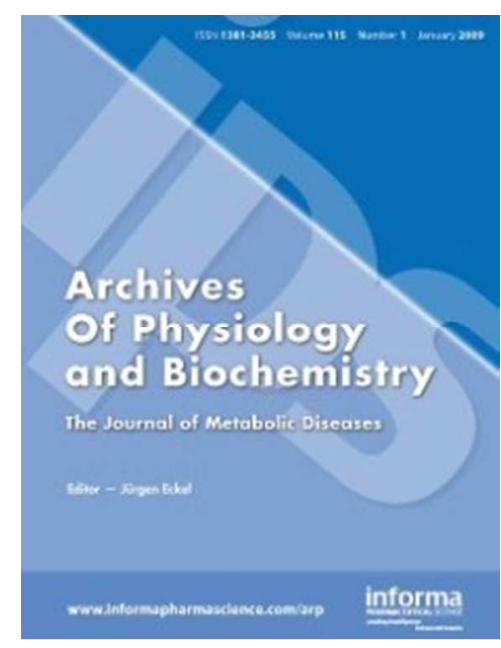

\title{
PCR array and protein array studies demonstrate that IL-1 $\beta$ (interleukin-1 $\beta$ ) stimulates the expression and secretion of multiple cytokines and chemokines in human adipocytes
}

\begin{tabular}{|r|l|}
\hline Journal: & Archives Of Physiology And Biochemistry \\
\hline Manuscript ID: & NAPB-2015-0039.R1 \\
\hline Manuscript Type: & Original Paper \\
\hline Date Submitted by the Author: & n/a \\
\hline Complete List of Authors: & $\begin{array}{l}\text { Alomar, Suliman; King Saud University, College of Science } \\
\text { Zaibi, Mohamed; University of Buckingham, } \\
\text { Kępczyńska, Malgorzata; University of Buckingham, } \\
\text { Gentili, Alessandra; University of Buckingham, } \\
\text { Alkhuriji, Afrah; King Saud University, College of Science } \\
\text { Mansour, Lamjad; King Saud University, College of Science } \\
\text { Dar, Javid; King Saud University, College of Science } \\
\text { Trayhurn, Paul; University of Liverpool, ; University of Buckingham, ; King } \\
\text { Saud University, College of Science }\end{array}$ \\
\hline Keywords: & \begin{tabular}{l} 
Adipose tissue, Gene expression, Inflammation, Obesity \\
\hline
\end{tabular} \\
\hline
\end{tabular}




\section{PCR array and protein array studies demonstrate that IL-1 $\beta$ (interleukin-1 $\beta$ ) stimulates the expression and secretion of multiple cytokines and chemokines in human adipocytes}

Suliman Y. Alomar ${ }^{1}$, Mohamed S. Zaibi ${ }^{2}$, Malgorzata A. Kępczyńska ${ }^{2}$, Alessandra Gentili ${ }^{2}$, Afrah Alkhuriji ${ }^{1}$, Lamjad Mansour ${ }^{1}$, Javid Ahmed Dar ${ }^{3}$, and Paul Trayhurn ${ }^{1,2}$

${ }^{1}$ Zoology Department, College of Science, King Saud University, Riyadh, Saudi Arabia; ${ }^{2}$ Clore Laboratory, Buckingham Institute for Translational Medicine, University of Buckingham, Buckingham, United Kingdom;

${ }^{3}$ Central Laboratory College of Science, King Saud University, Riyadh, Saudi Arabia

RUNNING TITLE: IL-1 $\beta$ stimulates inflammatory adipokines in human adipocytes

Keywords: Adipose tissue, gene expression, inflammation, obesity

*Correspondence should be addressed to:

Professor Paul Trayburn, FRSE

Clore Laboratory

Buckingham Institute for Translational Medicine

University of Buckingham

Hunter Street

Buckingham MK18 1EG, UK

Email: p.trayhurn@liverpool.ac.uk

Fax: $\quad+441280820135$ 


\begin{abstract}
The role of IL-1 $\beta$ in regulating the expression and secretion of cytokines and chemokines by human adipocytes was examined. Adipocytes were incubated with human IL-1 $\beta$ for 4 or $24 \mathrm{~h}$. The expression of a panel of 84 cytokine/chemokine genes was probed using PCR arrays. IL-1 $\beta$ stimulated the expression of $>30$ cytokine/chemokine genes on the arrays; 15 showed $>100$-fold increases in mRNA at 4 or $24 \mathrm{~h}$ including CSF3, CXCL1, CXCL2, CXCL12 and IL8. CSF3 exhibited a 10,000-fold increase in mRNA at $4 \mathrm{~h}$. ADIPOQ was among the genes whose expression was inhibited. Protein arrays were used to examine the secretion of cytokines/chemokines from adipocytes. IL-1 $\beta$ stimulated the secretion of multiple cytokines/chemokines including MCP-1, IL-8, IP-10, MIP-1 $\alpha$ and MCP-4. The most responsive was IP-10, which exhibited a 5,000-fold increase in secretion with IL-1 $\beta$. IL-1 $\beta$ is likely to play a substantial role in stimulating the inflammatory response in human adipocytes in obesity.
\end{abstract}




\section{Introduction}

Obesity is defined by an expansion in white adipose tissue mass, and changes in the tissue are considered to underlie the development of several obesity-associated diseases including insulin resistance and the metabolic syndrome (Kopelman, 2000; Hotamisligil, 2006; Rosen \& Spiegelman, 2006; Bluher, 2009). White adipose tissue is a major endocrine and secretory organ, with white adipocytes releasing a multiplicity of factors in the form of diverse adipokines, as well as fatty acids and other lipid moieties (Frühbeck et al., 2001; Trayhurn \& Beattie, 2001; Rajala et al., 2003; Trayhurn, 2013). A number of adipokines are associated with the immune system and inflammation, and the expression and secretion of some of these protein signals and factors rise in obesity (Rajala et al., 2003; Hotamisligil, 2006; Trayhurn, 2013); examples include TNF $\alpha$ (tumour necrosis factor $\alpha$ ), IL-6 (interleukin-6) and leptin. A notable exception is the hormone adiponectin, with its anti-inflammatory and insulin sensitising actions (Ouchi et al., 1999; Yokota et al., 2000; Berg et al., 2001; Yamauchi et al., 2001), the production and secretion of which falls as fat mass expands (Arita et al., 1999; Hotta et al., 2000). The establishment of an inflammatory state in adipose tissue in obesity, which includes the recruitment of activated macrophages and other immune cells (Weisberg et al., 2003; Xu et al., 2003; Pond, 2005; Bertola et al., 2012; Brestoff et al., 2015), is widely considered to underpin the development of the diseases associated with the obese state.

The factors which stimulate the production of inflammation-related adipokines have been widely examined in cell culture studies on rodent and human white adipocytes. The proinflammatory cytokine $\mathrm{TNF} \alpha$ has a substantial stimulatory effect, increasing the expression and release of other inflammation-related factors including IL-6, NGF (nerve growth factor), MCP-1 (monocyte chemoattractant protein-1), MMP1 and MMP3 (matrix metalloproteinases 1 and 3) (Wang et al., 2005; O'Hara et al., 2009). There has, however, been little focus on the extent to which another classical pro-inflammatory cytokine, IL-1 $\beta$ (interleukin-1 $\beta$ ) - which is implicated in a wide range of inflammatory diseases in other cells and tissues (see (Fietta et al., 2014; Lopalco et al., 2015)) - is important in stimulating the inflammatory response in adipocytes. Macrophage-conditioned medium has a major stimulatory effect on gene expression in human adipocytes and preadipocytes (Lacasa et al., 2007; O'Hara et al., 2009), particularly of matrix metalloproteinases and this effect on MMP expression and secretion is mimicked by IL- $1 \beta$ (O'Hara et al., 2012). IL-1 $\beta$ has also been shown to stimulate the expression and release of several cytokines and chemokines, including IL-6 and MCP-1, and these changes are accompanied by down-regulation of the production of proteins in the insulin signalling pathway 
(Gao et al., 2014). In the case of human pre-adipocytes, IL-1 $\beta$ has been identified as a key regulator of IL-6 production (O’Hara et al., 2012).

IL-1 $\beta$ is predicted to have extensive effects on the inflammatory response in human fat cells and this proposition has been examined in the present study. PCR arrays were used to measure the effect of IL-1 $\beta$ on the expression of a panel of 84 cytokine and chemokine genes, while protein arrays have been employed to determine the effects on the secretion of key inflammation-related adipokines.

\section{Materials and Methods}

Cell culture

Human fibroblastic preadipocytes (C-12730) and the requisite proprietary culture media were obtained from PromoCell (Germany). The cells had been isolated from the subcutaneous white adipose tissue of an obese Caucasian female, aged 59 years. The pre-adipocytes $(5,000$ cells $/ \mathrm{cm}^{2}$ ) were plated in 12-well plates and incubated in pre-adipocyte growth medium (C27410); this medium contains $5 \%$ fetal calf serum, epidermal growth factor $(10 \mathrm{ng} / \mathrm{ml})$, hydrocortisone $(1 \mu \mathrm{g} / \mathrm{ml})$ and heparin $(90 \mu \mathrm{g} / \mathrm{ml})$. When the cells had reached confluence (6-7 days), growth media was removed and the cells were incubated in pre-adipocyte differentiation medium (C-27436) to induce differentiation. The differentiation medium is supplemented with insulin $(0.5 \mu \mathrm{g} / \mathrm{ml})$, dexamathasone (400 $\mathrm{ng} / \mathrm{ml})$, IBMX $(44 \mu \mathrm{g} / \mathrm{ml})$, thyroxine $(9 \mathrm{ng} / \mathrm{ml})$ and ciglitazone $(3 \mu \mathrm{g} / \mathrm{ml})$, and does not contain fetal calf serum. After $72 \mathrm{~h}$ the cells were transferred to Adipocyte Nutrition Medium (C-27438); this medium contains 3\% fetal calf serum, insulin $(0.5 \mu \mathrm{g} / \mathrm{ml})$ and dexamethasone $(400 \mathrm{ng} / \mathrm{ml})$. The medium was changed every $2 / 3$ days and the cells were used at 12 days after the induction of differentiation, by which time they contained multiple lipid droplets. The presence of lipid droplets was confirmed by Oil Red O staining.

Human recombinant IL-1 $\beta$ (Sigma, UK) was added to the wells at a dose of $2 \mathrm{ng} / \mathrm{ml}$ which previous studies have demonstrated provides a maximal, or near-maximal, response in human fat cells (Gao \& Bing, 2011). Groups of adipocytes were treated with IL-1 $\beta$ for either $4 \mathrm{~h}$ or $24 \mathrm{~h}$ (from previous pilot studies, a near maximal response was evident at $4 \mathrm{~h}$ ); control cells were incubated without IL-1 $\beta$. After incubation, the medium was removed and the adipocytes washed with ice-cold PBS and frozen in TRI Reagent (Sigma UK) and stored at $-80^{\circ} \mathrm{C}$. The medium was stored at $-20^{\circ} \mathrm{C}$ until required for analysis at which point it was thawed and kept on ice during the plating of samples; the medium was not centrifuged prior to analysis so the presence of vesicular structures containing soluble and membrane-associated cytokines cannot be excluded. Six sets of cells were taken for each group. 


\section{RNA extraction}

Human adipocytes were homogenized in TRI Reagent (Sigma, UK) and total RNA isolated using the RNeasy ${ }^{\circledR}$ Micro Kit (SABiosciences, Qiagen, UK). The purity and concentration of RNA was quantified with a UV-Vis spectrophotometer (NanoDrop 1000, USA) in $1 \mu$ l samples; all samples had 260/280 nm and 260/230 nm average absorbance ratios of 2.0. The integrity of the RNA was analysed by an Agilent 2100 bioanalyser (Agilent Technologies, Germany). The RNA Integrity Number for RNA samples was equal to 10.

\section{PCR arrays}

Total RNA $(1.5 \mu \mathrm{g})$ was DNAse-treated and reverse transcribed using a $\mathrm{RT}^{2}$ First Strand Kit (SABiosciences, Qiagen, UK). Human cytokine and chemokine RT ${ }^{2}$ Profiler $^{\mathrm{TM}}$ PCR arrays with $\mathrm{SYBR}^{\circledR}$ Green were performed to screen the expression of 84 genes in mature human adipocytes exposed to IL-1 $\beta$; the strategy was similar to that employed previously using hypoxia signalling pathway arrays to investigate the effects of low $\mathrm{O}_{2}$ tension on gene expression in adipocytes (Wang et al., 2008). PCR amplification was performed using real-time PCR detection (ABI StepOneplus ${ }^{\mathrm{TM}}$, Applied Biosystems, USA) with a two-step thermal cycling: $95^{\circ} \mathrm{C}$ for $10 \mathrm{~min}$, followed by 40 cycles $\left(95^{\circ} \mathrm{C}\right.$ for $15 \mathrm{sec}, 60^{\circ} \mathrm{C}$ for $\left.1 \mathrm{~min}\right)$. Data were analysed using the comparative ${ }^{\Delta \Delta} \mathrm{Ct}$ method and expressed as fold-changes in the target gene normalised to the mean of endogenous control genes (ACTB, B2M, GAPDH, HPRT and RPLPO) in adipocytes treated with IL-1 $\beta$, and related to the expression of the untreated samples (normalised such that the controls = 1).

\section{Protein arrays}

Selected cytokines and chemokines released into the cell culture medium were measured using MSD Cytokines and Chemokines assay kits (Meso Scale Discovery, USA). These are sandwich immunoassays and provide a rapid and convenient method for measuring the levels of protein targets in a small volume sample. MSD plates were pre-coated with capture antibodies on independent and well-defined spots. Ten multi-spot plates were used: V-PLEX Cytokine Panel 1 human Kit (Ref: K15050D), V-PLEX Chemokine Panel 1 human Kit (Ref: K15047D) and VPLEX Pro-inflammatory Panel 1 human Kit (Ref: K15049D).

Briefly, $50 \mu \mathrm{l}$ samples or calibrators were added per well in duplicate and the plate was sealed and incubated at room temperature with shaking (700-1000 oscillations/min) for $2 \mathrm{~h}$. The plate was washed three times with $200 \mu \mathrm{l} /$ well of wash buffer and $25 \mu \mathrm{l}$ of detection antibody solution was added to each well. The plate was then sealed and incubated at room temperature with shaking (700-1000 oscillations/min) for a further $2 \mathrm{~h}$. Finally, the plate was washed as described previously and $150 \mu \mathrm{l}$ of reading buffer was added to each plate and read using a MSD 
instrument (SECTOR Imager 2400). The data were analysed using Meso Scale software. The lowest limit of detection was for IL-8 $(0.01 \mathrm{pg} / \mathrm{ml})$.

\section{Statistical analysis}

The statistical significance of differences between groups was assessed using Student's ' $t$ ' test.

\section{Results \\ Gene expression}

The human adipocytes used here were employed at 12 days after the induction of differentiation from fibroblastic preadipocytes. At this stage, they contained multiple lipid droplets as demonstrated by Oil Red O staining. The adipocytes were incubated with IL-1 $\beta$ for either 4 or $24 \mathrm{~h}$, in order to examine both acute and sustained responses to the cytokine. Gene expression in the cells was then probed with a pathway-specific PCR array for 84 cytokine and chemokine genes. Stringent criteria of a $>2.0$-fold increase in mRNA level at $P<0.05$ (or more), were employed to assess whether IL- $1 \beta$ had a significant effect on gene expression.

At $4 \mathrm{~h}$ of treatment with IL-1 $\beta$, the expression of 33 genes was significantly increased relative to control cells, amounting to >one-third of the genes represented on the arrays (Table 1). The most strongly upregulated genes were CSF3, CXCL2, CXCL1 and CXCL10, each of which showed $>1,000$-fold increases in mRNA level (Table 1). IL-1 $\beta$ mRNA level was also increased $>1,000$-fold at $4 \mathrm{~h}$, indicating a marked autocatalytic effect on the expression of the cytokine. Other cytokine and chemokine genes whose expression was stimulated by IL-1 $\beta$ at $4 \mathrm{~h}$ included IL6, IL7, IL8, IL15, CCL5, MCP1, MCP2, MCP3 and BMP2. In contrast to the substantial number of genes where expression was stimulated by IL-1 $\beta$, the expression of only three genes on the arrays was decreased at $4 \mathrm{~h}$; these were SPP1, IL16 and NODAL, which encode secreted phosphoprotein 1 (osteopontin), interleukin-16 and pro interleukin-16, respectively.

The mRNA level of slightly fewer genes was increased at $24 \mathrm{~h}$ of treatment with IL-1 $\beta$ than at $4 \mathrm{~h}-25$ genes compared with 33 at $4 \mathrm{~h}$ (Table 1). However, the pattern of stimulated genes was broadly similar at the two times. CSF3 was the most highly stimulated gene at $24 \mathrm{~h}$, as at $4 \mathrm{~h}$, with an increase in mRNA level of nearly 5,000-fold at the longer time-point. Other highly upregulated genes at $24 \mathrm{~h}$ were CCL5, CCL20, CCL19 and CXCL1, each of which exhibited a more than 1,000-fold increase in mRNA level. The highly pronounced autocatalytic effect on IL-1 $\beta$ expression had, however, terminated by $24 \mathrm{~h}$. Of the 25 genes whose expression was increased following $24 \mathrm{~h}$ treatment with IL-1 $\beta$, only CXCL12 exhibited an increase at $24 \mathrm{~h}$, but not at $4 \mathrm{~h}$. 
With some genes, such as CSF3, IL8, CCL3, LIF and CXCL10, the response to IL-1 $\beta$ was markedly lower at $24 \mathrm{~h}$ than at $4 \mathrm{~h}$. For other genes, expression was higher at $24 \mathrm{~h}$ than at 4 $\mathrm{h}$, and these include CCL5, CCL19 and CXCL5. Examples of the overall pattern of responses to IL-1 $\beta$ are shown in Fig. 1. More genes were downregulated by IL-1 $\beta$ at $24 \mathrm{~h}$ than at $4 \mathrm{~h}-11$ as compared with 3 - and only the expression of NODAL was significantly inhibited at both timepoints. Among the genes whose expression was decreased following $24 \mathrm{~h}$ treatment with IL-1 $\beta$ was $A D I P O Q$ (Fig. 1), which encodes the adipocyte hormone adiponectin. The expression of one gene, TGFB2, was significantly raised at $4 \mathrm{~h}$, but decreased at $24 \mathrm{~h}$.

\section{Protein secretion}

The production and release of selected cytokines and chemokines in response to IL-1 $\beta$ was then examined in the culture medium employing protein arrays. The proteins were selected primarily on the basis of the PCR array data, including those where there was a strong response to IL- $1 \beta$ and where the $\mathrm{Ct}$ values implied that sufficient quantities of the protein were likely to be secreted. The measurements were made only on the $24 \mathrm{~h}$ samples, to maximise the likelihood of detecting proteins of low abundance, and the culture medium was screened for a total of nearly 30 proteins.

The release of 23 of the proteins examined was stimulated by IL-1 $\beta$ by at least 2 -fold (Table 2). The proteins which showed the greatest concentration in the medium following treatment with IL-1 $\beta$ were IL-6, IL-8 and MCP-1, each of which was present at ng levels (between 2 and $8 \mathrm{ng} / \mathrm{ml}$ medium). The release of all three of these adipokines was substantially stimulated by IL-1 $\beta$; this was also the case for most of the other cytokines and chemokines on the arrays (Table 2). Several proteins, including IP-10 (interferon gamma-induced protein 10), TNF $\alpha$, IL-13, IL-4 and MIP-1 $\beta$ (macrophage inflammatory protein $1 \beta$ ), were either undetectable or barely detectable in the medium of control cells, secretion being only evident in the IL-1 $\beta$ treated adipocytes. This reflects the gene expression data where the mRNA was detected essentially only in treated cells. The overall pattern of responses to IL-1 $\beta$ are shown in Fig. 2.

The few examples of proteins where the release into the culture medium was not stimulated by IL-1 $\beta$ included IL-5, IL-16 and IL- $1 \alpha$. Indeed, IL- $1 \alpha$ was the sole protein of those examined where secretion was strongly inhibited by IL-1 $\beta$; although expression of the IL1 A gene was stimulated at $4 \mathrm{~h}$, at $24 \mathrm{~h}$ there was a decrease in mRNA level which was not, however, statistically significant. 


\section{Discussion}

The presence of inflammation in white adipose tissue in obesity, together with its link with the key diseases associated with the obese state (Hotamisligil, 2006; Rosen \& Spiegelman, 2006; Bluher, 2009), has resulted in interest in the factors that underlie and modulate the inflammatory response in fat cells. A number of studies have examined the role of TNF $\alpha$, a key proinflammatory factor, and of activators of PPAR $\gamma$. TNF $\alpha$ has, for example, been shown to stimulate the expression and release of multiple inflammation-related factors including IL-6, MCP-1, VEGF (vascular endothelial growth factor) and NGF, while inhibiting the production of leptin (Peeraully et al., 2004; Wang et al., 2005; Wang \& Trayhurn, 2006). TNF $\alpha$ is itself produced by adipocytes, being linked to the induction of insulin resistance (Hotamisligil et al., 1993), and this cytokine was one of the first adipokines to be identified.

In a recent study using bead arrays, LPS (lipopolysaccharide) was shown to stimulate the expression and release of multiple cytokines and chemokines in human adipocytes (Meijer et al., 2011). Adipocytes both exhibit immune cell functions and prime inflammation in a manner that it is independent of macrophages. Macrophages themselves not only participate directly in the inflammatory response in adipose tissue being recruited as tissue mass expands in obesity (Weisberg et al., 2003; Xu et al., 2003), but they also stimulate the production of inflammationrelated factors in fat cells. Microarray studies on human adipocytes, for example, have demonstrated that conditioned medium from macrophages stimulates the expression of multiple genes (in excess of 1000) (O'Hara et al., 2009). The major pathways modulated by macrophageconditioned medium in adipocytes encompass those involved in inflammation, macrophage infiltration, glucose uptake and lipid metabolism. Among the most highly up-regulated genes in human fat cells are several matrix metalloproteinases, particularly MMP1, MMP3 and MMP10 (O’Hara et al., 2009).

The secretion of MMPs from adipocytes is also strongly stimulated by macrophageconditioned medium, consistent with tissue remodelling during inflammation. This effect on both gene expression and release of the encoded protein is mimicked by TNF $\alpha$ (O'Hara et al., 2009). The extent to which other secreted factors from macrophages, particularly IL-1 $\beta$, stimulates the production of inflammation-related factors by adipocytes is essentially unknown, despite the central role of this cytokine in inflammation and disease processes in other tissues (Fietta et al., 2014; Lopalco et al., 2015). Nevertheless, IL-1 $\beta$ has been shown to be a regulator of IL-6 production by human preadipocytes (O'Hara et al., 2012), and to stimulate the expression and release of IL-6 and MCP-1 in human fat cells (Gao et al., 2014). IL-1 $\beta$, like TNF $\alpha$, is an adipokine, being synthesised and secreted by adipocytes themselves. As such, both adipocytes 
and macrophages are sources of IL-1 $\beta$ in adipose tissue, and the action of the cytokine on fat cells may be autocrine as well as paracrine.

The present study demonstrates that IL-1 $\beta$ has an extensive stimulatory effect on the expression and release of cytokines and chemokines in human adipocytes. Indeed, a wide range of these factors are clearly expressed and secreted by human fat cells, with production being markedly enhanced by IL-1 $\beta$. Quantitatively, the most important factors released in response to IL-1 $\beta$ were MCP-1, IL-8, IL-6, VEGF, IP-10 and MIP-1 $\alpha$, with IP-10 showing the largest proportionate increase in secretion. Substantial responses to IL-1 $\beta$ were also evident for IL-4, GM-CSF (granulocyte macrophage-colony-stimulating factor), TNF $\alpha$, IL12p70 (interleukin 12 subunit p70) and IFN $\gamma$ (interferon $\gamma$ ), but the absolute amount of these factors released over the $24 \mathrm{~h}$ culture period was much lower. GM-CSF, which is coded by CSF2, exhibited the largest response at the gene expression level in terms of the fold increase in mRNA level.

It is, of course, important to recognise that high 'fold increases' can reflect what may be negligible gene expression or protein secretion in control, un-treated cells, leading to the denominator being minimal. In the case of the protein measurements, for a small number of cytokines/chemokines the levels observed in the medium from control adipocytes were at, or close to, the limit of detection of the arrays. Thus, in some cases the fold-change in response to IL-1 $\beta$ is likely to be an under-estimate. In practise, what is significant is that IL- $1 \beta$ induces a substantial stimulation of the expression and secretion of key cytokines and chemokines, rather than the precise scale of response. It should also be noted that as with a number of such studies, a limitation of the present work is that the adipocytes were derived from a single donor.

Stimulation of the production and release of some of these proteins by LPS (Meijer et al., 2011), and also by TNF $\alpha$, has been observed previously in human adipocytes, as noted above. This includes IL-6 and MCP-1 in the case of TNF $\alpha$, while both IL-1 $\beta$ and LPS stimulate the secretion of factors such as IL-8, MIP-1 $\beta$, IP-10, eotaxin and GM-CSF (Meijer et al., 2011). There are, however, important differences in the response to IL-1 $\beta$ and LPS; for example, the secretion of IL-7 and IL-10 is reduced following treatment with LPS, while the expression and release of both these factors is stimulated by IL-1 $\beta$. This reflects the different receptors (and intracellular signalling systems) for IL-1 $\beta$ and LPS - respectively, IL-R1 and Toll-like receptor 4 (TLR-4).

Similarly, there are some differences in the response of human adipocytes to IL-1 $\beta$ as found here, and to macrophage-conditioned medium as observed in an earlier study (O'Hara et al., 2009). For example, most of the specific cytokines and chemokines on the PCR arrays whose expression was stimulated by IL-1 $\beta$ also exhibited a stimulation of expression on exposure to 
macrophage secretions. However, the expression of several genes, including CXCL10, CXCL11, CCL11, CCL19 and IL15, was not altered by macrophage-condition media, while their expression was stimulated by IL-1 $\beta$. Macrophages release, of course, a range of factors, including TNF $\alpha$. The difference between the response to macrophage-conditioned medium and IL-1 $\beta$ suggests that factors released from macrophages may inhibit, as well as stimulate, the expression of some inflammation-related genes, and in particular counteract the stimulatory effect of IL-1 $\beta$.

While many of the cytokines and chemokines synthesised and secreted from human adipocytes in the present study have been noted before (Meijer et al., 2011), MCP-4 has not been previously described as an adipokine. This factor has, nonetheless, been reported to be expressed in human adipose tissue (Hashimoto et al., 2006). While secretion of both eotaxin-3 and GMCSF is evident in this and a previous study on human fat cells in vitro (Meijer et al., 2011), their expression in adipose tissue in vivo has not been noted. Cytokines and chemokines are part of the totality of protein signals and factors synthesised and released by white adipocytes. The adipokines, which proteomic studies suggest number several hundred distinct entities (Dahlman et al., 2012; Rosenow et al., 2013), are involved in a diverse range of metabolic and physiological processes. It is evident that a multiplicity of chemoattractants and other pro- and antiinflammatory factors are synthesised and released by adipocytes as part of the inflammatory response in obesity.

Interestingly, a key inflammation-related adipokine whose production was downregulated by IL-1 $\beta$ is the major adipocyte hormone adiponectin. Adiponectin has an antiinflammatory action (Ouchi et al., 1999; Yokota et al., 2000), so inhibition of its synthesis would be expected to augment the pro-inflammatory effect of IL-1 $\beta$. However, the secretion of other anti-inflammatory factors, such as IL-10, was markedly stimulated by IL-1 $\beta$, and thus the overall effect of IL-1 $\beta$ on inflammation in adipose tissue is not uni-dimensional. In contrast to adiponectin, production of leptin, the other signature hormone of adipocytes, is stimulated by IL-1ß (Sarraf et al., 1997; Simons et al., 2007).

IL-1 $\beta$ is widely implicated in the development of type 2 diabetes, both in relation to insulin resistance and to impaired insulin secretion, and IL-1 $\beta$ antagonism and blockade of the IL-1 receptor are potential targets for the treatment of type 2 diabetes (Donath, 2014; Bing, 2015). At the level of the adipocyte, IL-1 $\beta$ has recently been shown to inhibit insulin signal transduction, this involving reduced expression of signalling proteins (Gao \& Bing, 2011). Insulin sensivity may also be impaired through the IL-1 $\beta$-induced suppression of adiponectin production. 


\section{Conclusions}

IL-1 $\beta$ is a major factor in the regulation of the expression and secretion of a wide range of cytokines and chemokines in human adipocytes. As would be expected, there are in particular powerful stimulatory effects of IL-1 $\beta$ on the production of key inflammation-related signals from fat cells. Within adipose tissue, IL-1 $\beta$ may be derived from macrophages or from the adipocytes themselves - or indeed, from other cells in the tissue. Comparison with the response to macrophage-conditioned medium indicates that multiple factors from macrophages are likely to be implicated in the regulation of the inflammatory response in adipocytes.

\section{Declarations of interest}

The authors acknowledge the Distinguished Scientist Fellowship Programme at King Saud University for financial support of this work. The authors also declare that they have no conflicts of interest in regard to this study. 
Table 1. Genes on cytokine and chemokine PCR pathway arrays whose expression was up- or down-regulated in human white adipocytes by treatment with IL-1 $\beta$

\begin{tabular}{|c|c|c|}
\hline Gene & $\begin{array}{c}\text { Change (fold) } \\
\text { with IL-1 } \beta \text { at } 4 \mathrm{~h}\end{array}$ & $\begin{array}{c}\text { Change (fold) } \\
\text { with IL-1 } \beta \text { at } 24 \text { h }\end{array}$ \\
\hline \multicolumn{3}{|l|}{ Upregulated: 4 and $24 \mathrm{~h}$} \\
\hline CSF3 & 9628 & 4649 \\
\hline CXCL2 & 1551 & 818 \\
\hline CXCL1 & 1537 & 1109 \\
\hline$V^{2}$ & 1138 & $6.99 * *$ \\
\hline CXCL10 & 1089 & 36.8 \\
\hline+2 & 759 & 310 \\
\hline 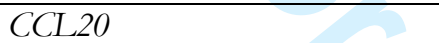 & 669 & 2277 \\
\hline CCL5 & 581 & 2433 \\
\hline CCL3 & 288 & 26.3 \\
\hline IL6 & 245 & 106 \\
\hline LIF & 2 & 11.9 \\
\hline CXCL11 & 148 & $17.3^{* *}$ \\
\hline CCL19 & 124 & 1594 \\
\hline CCL2 & 119 & 136 \\
\hline CSF2 & 57.0 & $3.27 *$ \\
\hline CCL7 & 51.4 & 9.56 \\
\hline CXCL5 & 45.2 & 148 \\
\hline IL1RN & 36.3 & 53.0 \\
\hline IL7 & 22.0 & 10.5 \\
\hline CCL11 & 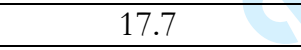 & 4.19 \\
\hline IL15 & 4.82 & 2.41 \\
\hline CX3CL1 & 4.64 & $2.27 * *$ \\
\hline CCL13 & 2.61 & 6.68 \\
\hline \multirow[t]{2}{*}{ CSF1 } & 2.57 & 2.39 \\
\hline & & 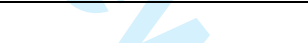 \\
\hline Upregulated: 4 h only & & 20 \\
\hline IL1A & 23.1 & +2 \\
\hline TNFA & 21.9 & \\
\hline CCL8 & 9.04 & \\
\hline TNFRSF11B & 7.90 & \\
\hline BMP2 & 5.12 & \\
\hline IL23A & 5.06 & \\
\hline CCL1 & $3.19 *$ & \\
\hline TGFB2 & 2.84 & \\
\hline IL12A & $2.26^{* *}$ & \\
\hline \multicolumn{3}{|l|}{ Upregulated: 24 h only } \\
\hline CXCL12 & & 4.07 \\
\hline \multicolumn{3}{|l|}{ Downregulated: 4 and $24 \mathrm{~h}$} \\
\hline NODAL & $0.275^{* *}$ & $0.438^{*}$ \\
\hline IL16 & 0.371 & 0.438 \\
\hline \multicolumn{3}{|l|}{ Downregulated: 4 h only } \\
\hline SIPP1 & 0.400 & \\
\hline
\end{tabular}

12

URL: http://mc.manuscriptcentral.com/napb Email: eckel@uni-duesseldorf.de 


\begin{tabular}{|l|l|l|}
\hline & & \\
\hline Downregulated: 24 h only & & \\
\hline IL18 & & $0.466^{* *}$ \\
\hline IFNA2 & & $0.349^{*}$ \\
\hline BMP4 & & 0.339 \\
\hline IL24 & & $0.305^{* *}$ \\
\hline TNFSF13B & & 0.267 \\
\hline C5 & & 0.263 \\
\hline TGFB2 & & 0.248 \\
\hline ADIPOQ & & 0.229 \\
\hline TNFSF10 & & 0.145 \\
\hline & & \\
\hline
\end{tabular}

Human adipocytes differentiated from preadipocytes in culture were incubated in the presence or absence of human recombinant IL-1 $\beta(2 \mathrm{ng} / \mathrm{ml})$ and cytokine and chemokine gene expression probed with PCR pathway arrays. The genes listed are those where there was a statistically significant $(P<0.05$ or more) change in relative mRNA level of at least 2 -fold between IL-1 $\beta$ treated and control adipocytes (controls normalised to $=1.0$ ); all fold-changes are significant at $P<0.001$, except those marked $*$ or ** where $P<0.05$ or $P<0.01$, respectively. The fold-changes are derived from 5-6 groups of adipocytes at both 4 and $24 \mathrm{~h}$. 


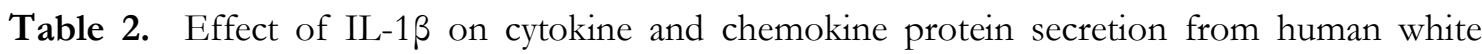
adipocytes

\begin{tabular}{|c|c|c|c|}
\hline Protein & $\begin{array}{l}\text { Control } \\
(\mathrm{pg} / \mathrm{ml})\end{array}$ & $\begin{array}{c}\text { IL- } 1 \beta \text { treated } \\
(\mathrm{pg} / \mathrm{ml})\end{array}$ & $\begin{array}{l}\text { Fold-change } \\
\text { with IL-1 } \beta\end{array}$ \\
\hline IP-10 (interferon gamma-induced protein 10) & $0.05 \pm 0.02$ & $251.2 \pm 28.9$ & 5127 \\
\hline IL-4 (interleukin-4) & $0.01 \pm 0.00$ & $2.38 \pm 0.14$ & 380 \\
\hline IL-6 (interleukin-6) & $6.00 \pm 0.19$ & $2184 \pm 19$ & 364 \\
\hline $\begin{array}{l}\text { GM-CSF (granulocyte macrophage-colony- } \\
\text { stimulating factor) }\end{array}$ & $0.04 \pm 0.01$ & $12.64 \pm 0.60$ & 330 \\
\hline TNF $\alpha$ (tumour necrosis factor $\alpha)$ & $0.03 \pm 0.01$ & $5.55 \pm 0.32$ & 168 \\
\hline IL12p70 (interleukin 12 subunit p70) & $0.04 \pm 0.01$ & $5.38 \pm 0.53$ & 129 \\
\hline IL-8 (interleukin-8) & $54.68+2.02$ & $6330 \pm 23$ & 116 \\
\hline IL-10 (interleukin-10) & $0.02 \pm 0.00$ & $2.33 \pm 0.16$ & 108 \\
\hline IFN $\gamma$ (interferon $\gamma)$ & $0.09 \pm 0.03$ & $9.45 \pm 0.32$ & 104 \\
\hline MIP-1 $\beta$ (macrophage inflammatory protein $1 \beta$ ) & $0.27 \pm 0.02$ & $17.89 \pm 1.30$ & 67.3 \\
\hline MIP-1 $\alpha$ (macrophage inflammatory protein $1 \alpha)$ & $1.90 \pm 0.20$ & $105.9 \pm 3.9$ & 55.7 \\
\hline MCP-1 (monocyte chemoattractant protein 1) & $207.6+15.7$ & $7000 \pm 152$ & 33.7 \\
\hline IL-13 (interleukin-13) & $0.47 \pm 0.06$ & $13.56 \pm 0.29$ & 28.7 \\
\hline IL-2 (interleukin-2) & $0.09 \pm 0.02$ & $2.54 \pm 0.09$ & 27.9 \\
\hline MDC (macrophage-derived chemokine) & $1.71 \pm 0.48$ & $47.27 \pm 10.72^{* *}$ & 27.7 \\
\hline Eotaxin & $0.47 \pm 0.13$ & $11 . \overline{62} \pm 0.92$ & 24.7 \\
\hline MCP-4 (monocyte chemoattractant protein 4) & $0.44 \pm 0.08$ & $10.41 \pm 0.57$ & 23.9 \\
\hline Eotaxin-3 & $0.97 \pm 0.43$ & $17.94 \pm 6.47^{*}$ & 18.6 \\
\hline $\begin{array}{l}\text { TARC (thymus and activation regulated } \\
\text { chemokine) }\end{array}$ & $0.58 \pm 0.08$ & $7.43 \pm 1.35$ & 12.8 \\
\hline IL-7 (interleukin-7) & $0.82 \pm 0.05$ & $5.66 \pm 0.21$ & 6.93 \\
\hline VEGF (vascular endothelial growth factor) & $204.8 \pm 2.6$ & $648.4 \pm 17.1$ & 3.17 \\
\hline IL-15 (interleukin-15) & $0.29 \pm 0.01$ & $0.67 \pm 0.03$ & 2.30 \\
\hline IL-16 (interleukin-15) & $0.07 \pm 0.05$ & $0.14 \pm 0.05^{\mathrm{NS}}$ & 2.12 \\
\hline IL-17 (interleukin-17) & $0.06 \pm 0.03$ & $0.13 \pm 0.03^{\mathrm{NS}}$ & 2.11 \\
\hline TNF $\beta$ (tumour necrosis factor $\beta$ ) & $0.03 \pm 0.01$ & $0.05 \pm 0.01^{*}$ & 1.81 \\
\hline IL12p40 (interleukin 12 subunit p40) & $0.13 \pm 0.04$ & $0.22 \pm 0.04^{\mathrm{NS}}$ & 1.60 \\
\hline IL-5 (interleukin-5) & $0.10 \pm 0.02$ & $0.11 \pm 0.02^{\mathrm{NS}}$ & 1.08 \\
\hline IL-1 $\alpha$ (interleukin-1 $\alpha)$ & $0.42 \pm 0.40$ & $0.03 \pm 0.01^{\mathrm{NS}}$ & 0.07 \\
\hline IL-1 $\beta$ (interleukin-1 $\beta$ ) & $0.03 \pm 0.00$ & $280.3 \pm 4.1$ & 10376 \\
\hline & & 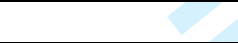 & \\
\hline
\end{tabular}

Human adipocytes differentiated from preadipocytes in culture were incubated in the presence or absence of human recombinant IL-1 $\beta$ ( $2 \mathrm{ng} / \mathrm{ml})$. Protein arrays were used to screen the effect of IL-1 $\beta$ on cytokine and chemokine secretion into the medium over $24 \mathrm{~h}$. The differences between the IL-1 $\beta$ treated and control cells were statistically significant at $P<0.001$, except those marked $*$ and $* *$ where $P<0.05$ and $P<0.01$, respectively. NS, not significant $(P>0.05)$. The results are the means \pm SE of 5-6 groups of adipocytes. IL- $1 \beta$ is shown to illustrate the very low basal levels of secretion of this cytokine. The lowest detection limit was for IL-8 $(0.01 \mathrm{pg} / \mathrm{ml})$. 


\section{References}

Arita Y, Kihara S, Ouchi N, Takahashi M, Maeda K, Miyagawa J, Hotta K, Shimomura I, Nakamura T, Miyaoka K, Kuriyama H, Nishida M, Yamashita S, Okubo K, Matsubara K, Muraguchi M, Ohmoto Y, Funahashi T, Matsuzawa Y. 1999. Paradoxical decrease of an adipose-specific protein, adiponectin, in obesity. Biochem Biophys Res Commun 257:79-83.

Berg AH, Combs TP, Du X, Brownlee M, Scherer PE. 2001. The adipocyte-secreted protein Acrp30 enhances hepatic insulin action. Nature Med 7:947-53.

Bertola A, Ciucci T, Rousseau D, Bourlier V, Duffaut C, Bonnafous S, Blin-Wakkach C, Anty R, Iannelli A, Gugenheim J, Tran A, Bouloumié A, Gual P, Wakkach A. 2012. Identification of adipose tissue dendritic cells correlated with obesity-associated insulinresistance and inducing Th17 responses in mice and patients. Diabetes 61:2238-47.

Bing C. 2015. Is interleukin-1 $\beta$ a culprit in macrophage-adipocyte crosstalk in obesity? Adipocyte 4:149-52.

Bluher M. 2009. Adipose tissue dysfunction in obesity. Exp Clin Endocrinol Diabetes 117:241-50.

Brestoff JR, Kim BS, Saenz SA, Stine RR, Monticelli LA, Sonnenberg GF, Thome JJ, Farber DL, Lutfy K, Seale P, Artis D. 2015. Group 2 innate lymphoid cells promote beiging of white adipose tissue and limit obesity. Nature 519:242-6.

Dahlman I, Elsen M, Tennagels N, Korn M, Brockmann B, Sell H, Eckel J, Arner P. 2012. Functional annotation of the human fat cell secretome. Arch Physiol Biochem 118:84-91.

Donath MY. 2014. Targeting inflammation in the treatment of type 2 diabetes: time to start. Nature Rev Drug Discov 13:465-76.

Fietta P, Costa E, Delsante G. 2014. Interleukins (ILs), a fascinating family of cytokines. Part I: ILs from IL-1 to IL-19. Theor Biol Forum 107:13-45.

Frühbeck G, Gómez-Ambrosi J, Muruzabal FJ, Burrell MA. 2001. The adipocyte: a model for integration of endocrine and metabolic signaling in energy metabolism regulation. Am J Physiol 280:E827-E47.

Gao D, Bing C. 2011. Macrophage-induced expression and release of matrix metalloproteinase 1 and 3 by human preadipocytes is mediated by IL- $1 \beta$ via activation of MAPK signaling. $J$ Cell Physiol 226:2869-80.

Gao D, Madi M, Ding C, Fok M, Steele T, Ford C, Hunter L, Bing C. 2014. Interleukin-1 $\beta$ mediates macrophage-induced impairment of insulin signaling in human primary adipocytes. Am J Physiol Endocrinol Metab 307:E289-E304. 
Hashimoto I, Wada J, Hida A, Baba M, Miyatake N, Eguchi J, Shikata K, Makino H. 2006. Elevated serum monocyte chemoattractant protein-4 and chronic inflammation in overweight subjects. Obesity 14:799-811.

Hotamisligil GS, Shargill NS, Spiegelman BM. 1993. Adipose expression of tumor necrosis factor- $\alpha$ - direct role in obesity-linked insulin resistance. Science 259:87-91.

Hotamisligil GS. 2006. Inflammation and metabolic disorders. Nature 444:860-67.

Hotta K, Funahashi T, Arita Y, Takahashi M, Matsuda M, Okamoto Y, Iwahashi H, Kuriyama H, Ouchi N, Maeda K, Nishida M, Kihara S, Sakai N, Nakajima T, Hasegawa K, Muraguchi M, Ohmoto Y, Nakamura T, Yamashita S, Hanafusa T, Matsuzawa Y. 2000. Plasma concentrations of a novel, adipose-specific protein, adiponectin, in type 2 diabetic patients. Arterioscl Thromb V asc Biol 20:1595-99.

Kopelman PG. 2000. Obesity as a medical problem. Nature 404:635-43.

Lacasa D, Taleb S, Keophiphath M, Miranville A, Clement K. 2007. Macrophage-secreted factors impair human adipogenesis: involvement of proinflammatory state in preadipocytes. Endocrinology 148:868-77.

Lopalco G, Cantarini L, Vitale A, Iannone F, Anelli MG, Andreozzi L, Lapadula G, Galeazzi M, Rigante D. 2015. Interleukin-1 as a common denominator from autoinflammatory to autoimmune disorders: premises, perils, and perspectives. Mediat Inflamm 2015:194864.

Meijer K, de Vries M, Al-Lahham S, Bruinenberg M, Weening D, Dijkstra M, Kloosterhuis N, van der Leij RJ, van der Want H, Kroesen BJ, Vonk R, Rezaee F. 2011. Human primary adipocytes exhibit immune cell function: adipocytes prime inflammation independent of macrophages. PLoS One 6:e17154.

O'Hara A, Lim F-L, Mazzatti D, Trayhurn P. 2009. Microarray analysis identifies matrix metalloproteinases (MMPs) as key genes whose expression is up-regulated in human adipocytes by macrophage-conditioned medium. Pflïgers Archiv Eur J Physiol 458:1103-14.

O'Hara A, Lim F-L, Mazzatti DJ, Trayhurn P. 2012. Stimulation of inflammatory gene expression in human preadipocytes by macrophage-conditioned medium: Upregulation of IL-6 production by macrophage-derived IL-1ß. Mol Cell Endocrinol 349:239-47.

Ouchi N, Kihara S, Arita Y, Maeda K, Kuriyama H, Okamoto Y, Hotta K, Nishida M, Takahashi M, Nakamura T, Yamashita S, Funahashi T, Matsuzawa Y. 1999. Novel modulator for endothelial adhesion molecules - Adipocyte-derived plasma protein adiponectin. Circulation 100:2473-76. 
Peeraully MR, Jenkins JR, Trayhurn P. 2004. NGF gene expression and secretion in white adipose tissue: regulation in 3T3-L1 adipocytes by hormones and inflammatory cytokines. Am J Physiol Endocrinol Metab 287:E331-E39.

Pond CM. 2005. Adipose tissue and the immune system. Prost Leuk Essent Fatty Acids 73:17-30.

Rajala MW, Obici S, Scherer PE, Rossetti L. 2003. Adipose-derived resistin and gut-derived resistin-like molecule- $\beta$ selectively impair insulin action on glucose production. $J$ Clin Invest 111:225-30.

Rosen ED, Spiegelman BM. 2006. Adipocytes as regulators of energy balance and glucose homeostasis. Nature 444:847-53.

Rosenow A, Noben JP, Bouwman FG, Mariman EC, Renes J. 2013. Hypoxia-mimetic effects in the secretome of human preadipocytes and adipocytes. Biochim Biophys Acta 1834:276171.

Sarraf P, Frederich RC, Turner EM, Ma G, Jaskowiak NT, Rivet DJ, Flier JS, Lowell BB, Fraker DL, Alexander HR. 1997. Multiple cytokines and acute inflammation raise mouse leptin levels: Potential role in inflammatory anorexia. J Exp Med 185:171-75.

Simons PJ, van den Pangaart PS, Aerts JMFG, Boon L. 2007. Pro-inflammatory delipidizing cytokines reduce adiponectin secretion from human adipocytes without affecting adiponectin oligomerization. J Endocrinol 192:289-99.

Trayhurn P, Beattie JH. 2001. Physiological role of adipose tissue: white adipose tissue as an endocrine and secretory organ. Proc Nutr Soc 60:329-39.

Trayhurn P. 2013. Hypoxia and adipose tissue function and dysfunction in obesity. Physiol Rev 93:1-21.

Wang B, Jenkins JR, Trayhurn P. 2005. Expression and secretion of inflammation-related adipokines by human adipocytes differentiated in culture: Integrated response to TNF- $\alpha$. Am J Physiol Endocrinol Metab 288:E731-E40.

Wang B, Trayhurn P. 2006. Acute and prolonged effects of TNF-alpha on the expression and secretion of inflammation-related adipokines by human adipocytes differentiated in culture. Pflïgers Archiv Eur J Physiol 452:418-27.

Wang B, Wood IS, Trayhurn P. 2008. PCR arrays identify metallothionein-3 as a highly hypoxiainducible gene in human adipocytes. Biochem Biophys Res Commun 368:88-93.

Weisberg SP, McCann D, Desai M, Rosenbaum M, Leibel RL, Ferrante AW, Jr. 2003. Obesity is associated with macrophage accumulation in adipose tissue. J Clin Invest 112:1796-808. 
Xu H, Barnes GT, Yang Q, Tan G, Yang D, Chou CJ, Sole J, Nichols A, Ross JS, Tartaglia LA, Chen H. 2003. Chronic inflammation in fat plays a crucial role in the development of obesity-related insulin resistance. J Clin Invest 112:1821-30.

Yamauchi T, Kamon J, Waki H, Terauchi Y, Kubota N, Hara K, Mori Y, Ide T, Murakami K, Tsuboyama-Kasaoka N, Ezaki O, Akanuma Y, Gavrilova O, Vinson C, Reitman ML, Kagechika H, Shudo K, Yoda M, Nakano Y, Tobe K, Nagai R, Kimura S, Tomita M, Froguel P, Kadowaki T. 2001. The fat-derived hormone adiponectin reverses insulin resistance associated with both lipoatrophy and obesity. Nature Med 7:941-6.

Yokota T, Oritani K, Takahashi I, Ishikawa J, Matsuyama A, Ouchi N, Kihara S, Funahashi T, Tenner AJ, Tomiyama Y, Matsuzawa Y. 2000. Adiponectin, a new member of the family of soluble defense collagens, negatively regulates the growth of myelomonocytic progenitors and the functions of macrophages. Blood 96:1723-32. 


\section{Legends to Figures}

Figure 1. Illustration of patterns of effects of IL-1 $\beta$ on cytokine and chemokine gene expression in human adipocytes. The results show the fold-changes in mRNA level for adipocytes treated with IL-1 $\beta$ compared with controls (controls normalised to 1 ) at 4 and $24 \mathrm{~h}$. All differences shown reflect statistically significant changes $(P<0.001)$ in mRNA level between IL-1 $\beta$ treated and control adipocytes, except for $A D I P O Q$ at $4 \mathrm{~h}$. The fold-changes are derived from 5-6 groups of adipocytes at both 4 and $24 \mathrm{~h}$.

Figure 2. Examples of pattern of effects of IL-1 $\beta$ on cytokine and chemokine protein secretion by human adipocytes. Data, which are for $24 \mathrm{~h}$, are means \pm SE (bars) for 5-6 groups of adipocytes. Differences were statistically significant $(P<0.001)$ between IL-1 $\beta$ treated and control adipocytes, except those marked NS (not significant, $P>0.05$ ). 

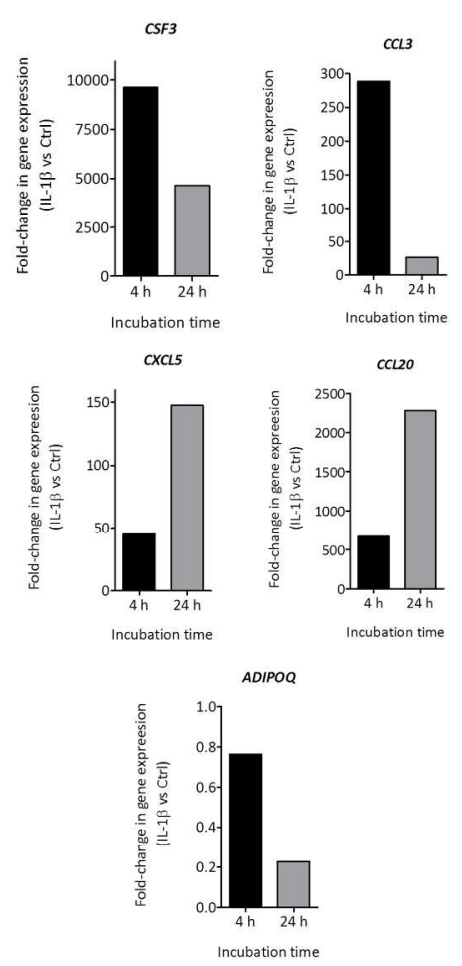

$209 \times 296 \mathrm{~mm}(263 \times 263 \mathrm{DPI})$ 

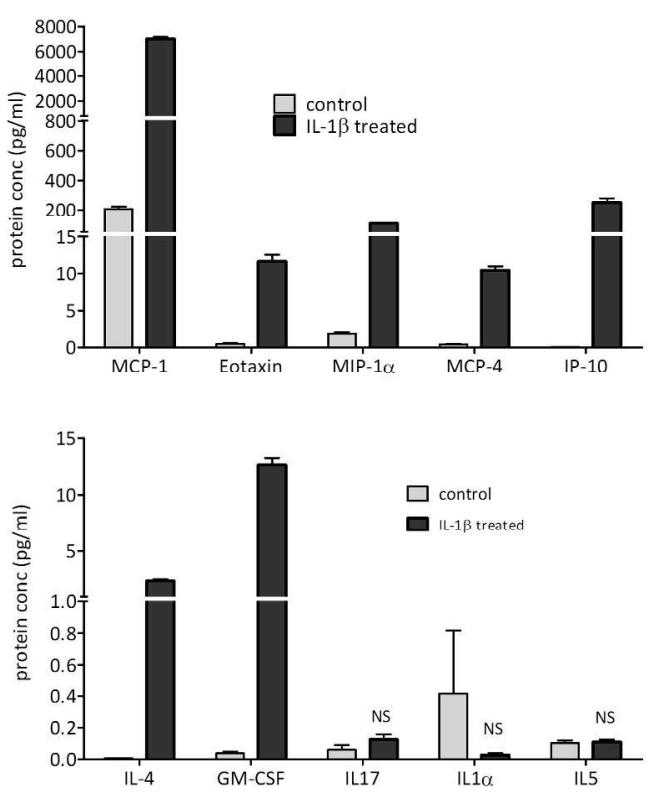

$209 \times 296 \mathrm{~mm}(263 \times 263 \mathrm{DPI})$ 